\title{
GRAPHICAL TOOL FOR HYBRID FUEL CELL MODELLING AND SIMULATION
}

\author{
Tsvetelina Georgieva, Velizara Pencheva, Asen Asenov, \\ Sechkin Remzi \& Plamen Daskalov
}
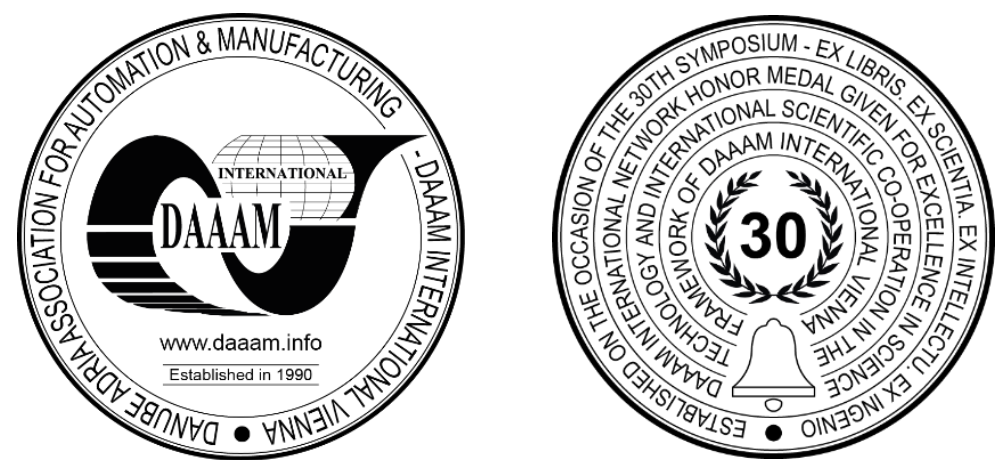

This Publication has to be referred as: Georgieva, T[svetelina]; Pencheva, V[elizara]; Asenov, A[sen]; Remzi, S[echkin] \& Daskalov, P[lamen] I[vanov] (2020). Graphical Tool for Hybrid Fuel Cell Modelling and Simulation, Proceedings of the 31st DAAAM International Symposium, pp.0656-0660, B. Katalinic (Ed.), Published by DAAAM International, ISBN 978-3-902734-29-7, ISSN 1726-9679, Vienna, Austria DOI: $10.2507 / 31$ st.daaam.proceedings.091

\begin{abstract}
A structure of graphical tool for hybrid fuel cell modelling, simulation and optimization is presented in the paper. The model of the tool combines Simulink modelling and simulation, statistical approaches, optimizing procedures of hybrid systems for different types of vehicles - cars, buses or boats. Modelling of the hybrid fuel cell is based on parameters of the used vehicle. Simulation visualize different characteristics of the hybrid system parameters. Optimization of different parameters and energy management system will be based on fuzzy logic and genetic algorithms. The tool is based on different modules and could be upgrade with other additional functions. A software graphical tool is developed in a form of Graphical user interface, based on the presented model, using MATLAB@7.1 GUIDE template editor and systems functions.
\end{abstract}

Keywords: Graphical User Tool; Hybrid Fuel Cell; Modelling; Matlab; Optimization; Module-Based Structure

\section{Introduction}

Fuel cells are a transient technology for producing electricity from hydrogen or other high efficiency and low emission fuels [1], [2]. They are suitable for stationary, transport and portable applications [3]. However, they are still more expensive than existing technologies and there are technical challenges that must be overcome for their commercialization. Therefore, accurate and efficient methodologies for the design of fuel cell systems are becoming increasingly necessary and significant. Modeling and optimization [4], [5] present great potential in the design of fuel cell systems, which often results in design time and cost savings, as well as better design and operation.

Fuel cell systems are being developed for a wide variety of applications in energy production. They are mainly used for transport applications in cars, buses, utility vehicles, scooters and bicycles; to produce energy for buildings, in which case they are used for both energy and heat generated by fuel cells; for portable applications, either as standby power generators or as battery replacements in various electronic devices and gadgets. However, fuel cells are still more expensive than existing technologies. There are also many technical and non-technical challenges that need to be overcome. 
Major technical problems include the following [6]:

- reducing costs in all aspects of the production of fuel cells, materials, systems and applications, as well as other components;

- demonstration of the durability, reliability and availability of fuel cells;

- fuel choice and price;

- improving productivity.

- Non-technical problems are:

- estimation of external costs (emissions, environmental, safety and health, etc.);

- the socio-economic consequences of the introduction of new fuel cell technologies;

- identifying problems with the development of commercial fuel cells;

- availability of investment and venture capital to provide new combustion infrastructure and production facilities.

These are just some of the reasons why research and development of fuel cell systems has been needed in recent years. Approaches for modelling and simulation of hybrid fuel cells are presented in the paper. New software tool for automation of processing, analysis and identification of hybrid systems battery/fuel cell was developed in MATLAB. MATLAB [7] allows the creation of a Windows - based window applications, which use different means of handling 2D and 3D objects. MATLAB offers a large set of components used in the design of graphical user interfaces. It has high computing power and is suitable for operations with matrices. The possibility to create standalone applications, which launching does not require MATLAB is advantage of the programming environment. The purpose of this article is to develop and describe the structure of a graphical tool for modelling and simulation of hybrid fuel cell systems. The future research will be focus on test and assessment of this system.

\section{Modelling of fuel cell systems}

Modelling of a fuel cell system [8] is based on and includes mathematical models of its basic elements - fuel cell, battery, bidirectional DC/DC converter, electric motor with its corresponding control, transmission and the main mass and geometric parameters of the vehicle [10]. For example, when modelling a car with hybrid electric drive, it is necessary to have a clear diagram of the connection of the energy sources - fuel cell and battery.

The next major step is to determine the operating modes of the drive system. The fuel cell operating area is also defined as the criterion for determining the load area in which the fuel cell is to operate is the operation with the highest efficiency. The following input data are required to perform the calculations for the resistance forces and moments when the vehicle is traveling: maximum travel speed; frontal area of the vehicle; coefficient of drag of the vehicle; number of passengers; payload mass; vehicle own weight not including fuel cell mass, hydrogen tanks, battery weight.

The fuel cell model describes it as a fuel cell using pure hydrogen and oxygen from ambient air. It is assumed that the operating temperature and pressure of hydrogen and air are optimal for the operation of the system. The voltage-current characteristic of a hydrogen fuel cell, described by equation, consists of three zones. In the first zone, losses from activation polarization have the greatest influence. The width of the zone depends on the operating temperature and pressure, the type of electrodes and catalysts used. The second zone is characterized by losses of internal electrical resistance in the fuel cells. In the third zone, the losses from concentration polarization have a major influence.

In the mathematical model of the system, the battery is modelled by its voltage-ampere characteristic and its degree of charge. The required power is determined and the motor is selected. Hydrogen consumption is also calculated, based on specific energy and energy density. The system is moved to the software environment to perform the simulation analysis when the necessary parameters for the calculations are known.

The model of these systems [11] is mainly used to study the relationship between fuel consumption and electricity produced, to compare different operational strategies for micro-cogeneration and to study the interaction between operating modes and the power grid. With the right wording [12], models would be useful tools in the design of fuel cell systems, because they would provide information about the behavior of the system, based on which to take informed decisions, apply different design alternatives, and develop the most effective solution for the particular case.

\section{Structure of the graphical tool for hybrid systems}

A software graphical tool for hybrid systems, which includes five main modules (Fig. 1), is presented. The structure of the developed instrument is hierarchical. System functions and tools of the editor GUIDE templates are used for modules programming implementation. The graphical tool consists of four modules: modelling, simulation, optimization and storage of results. The "Modelling" module allows the user to enter the vehicle type car, bus or boat, presented in Figure 2.

After selecting the vehicle, a new user window will be loaded, in which the user will enter the necessary data for the modelling, simulation and optimization of the hybrid systems [13]. This data will be entered into the fields that will be entered with a boundary, so that no errors are made in the information input and then in the calculations. 


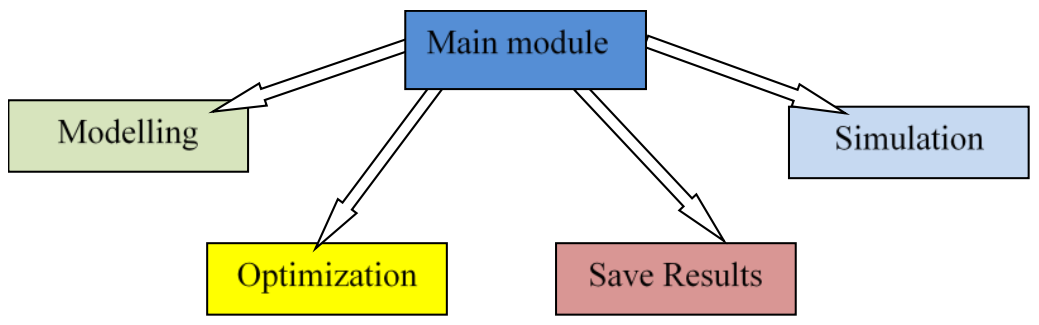

Fig. 1. Structure of the graphical tool for hybrid systems

The "Simulation" module will allow to simulate the model of a hybrid system introduced by the user or to load from a file a previously developed and stored model of such system. The "Optimization" module will allow you to optimize the system for various parameters that the user will be able to set from the drop-down menu [14],[15],[16]. The "Save Results" module will allow the results to be stored, and the user can optionally specify the name of the file and the location. Modelling of the hybrid fuel cell is based on parameters of the used vehicle. Simulation visualize different characteristics of the hybrid system parameters. Optimization of different parameters and energy management system will be based on fuzzy logic and genetic algorithms. The main module of the graphical user tool is presented on fig. 2.

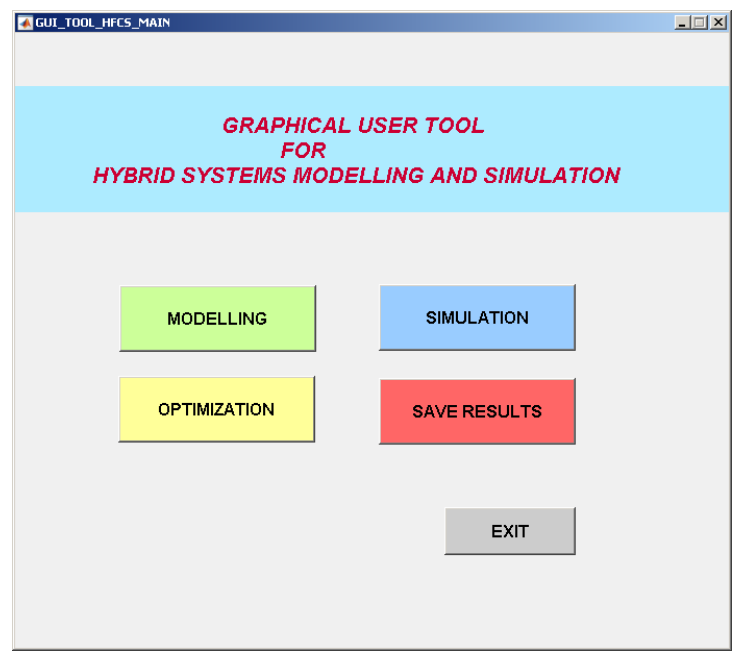

a)

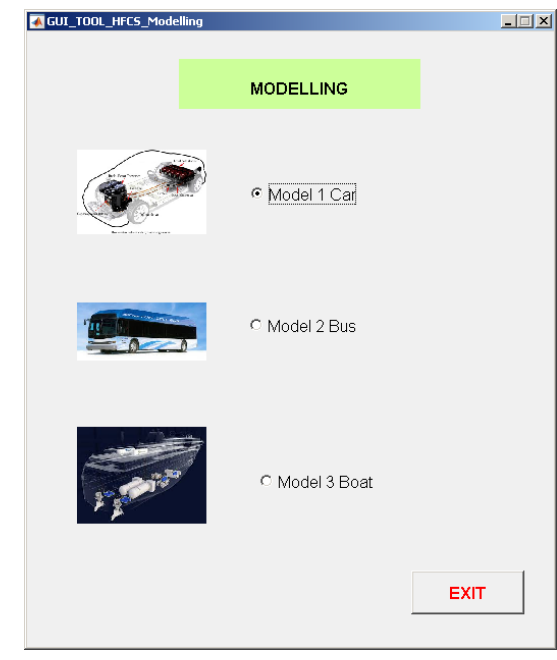

b)

Fig. 2. Main module and module "Modelling" of the graphical user tool for hybrid systems a) Main module; b) module "Modelling"

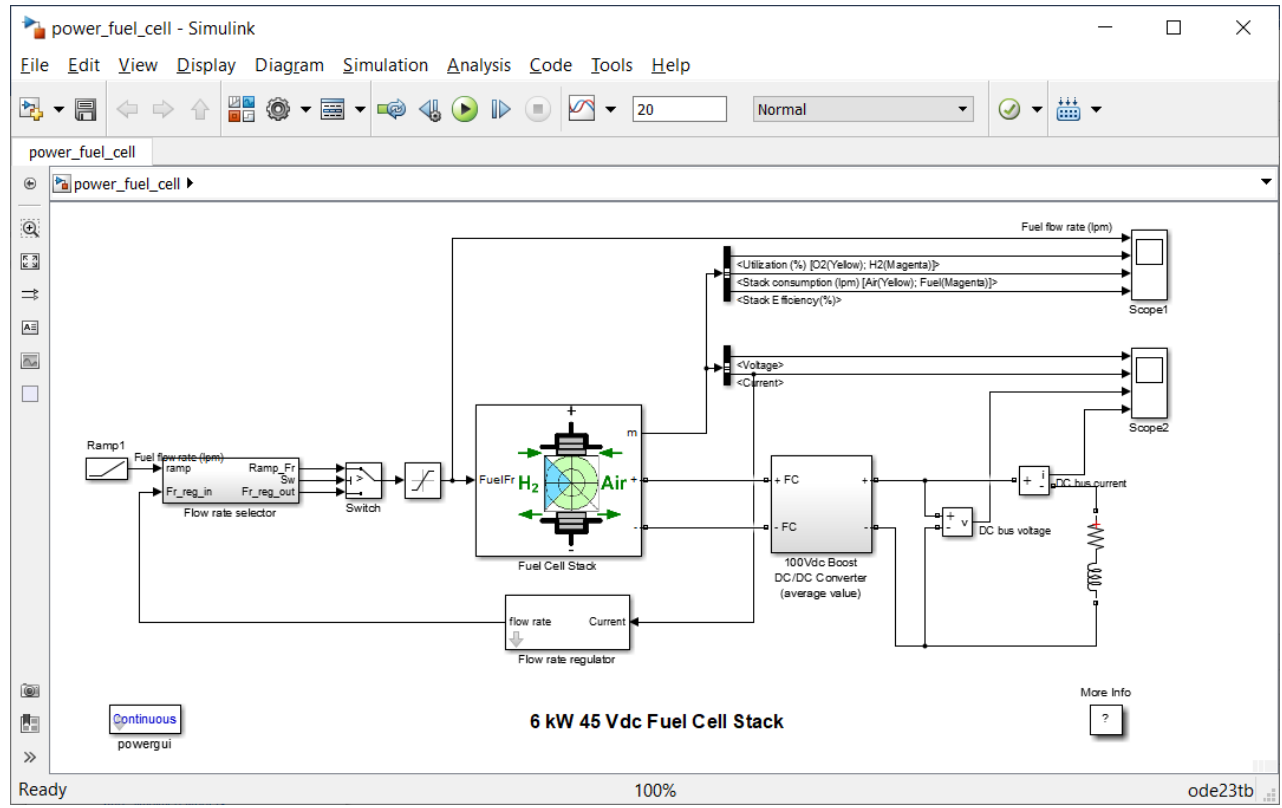

Fig. 3. Fuel cell stack model in MATLAB/Simulink 
The MATLAB environment was chosen for the development of the graphical tool because it allows to modularly create models of the basic elements of hybrid systems, as well as to integrate into the tool functions that were developed in the MATLAB environment. The example of using the fuel cell MATLAB/Simulink model is presented on fig. 3 [17]. In the simulation, the results will be displayed graphically, as well as the necessary values from the calculations. Example of the visualized results which presents basic characteristics of the systems is shown on fig. 4. The developed graphical tool will be helpful tool of the researchers in the field of hybrid systems for modelling, simulation, optimization and analyze the obtained results.

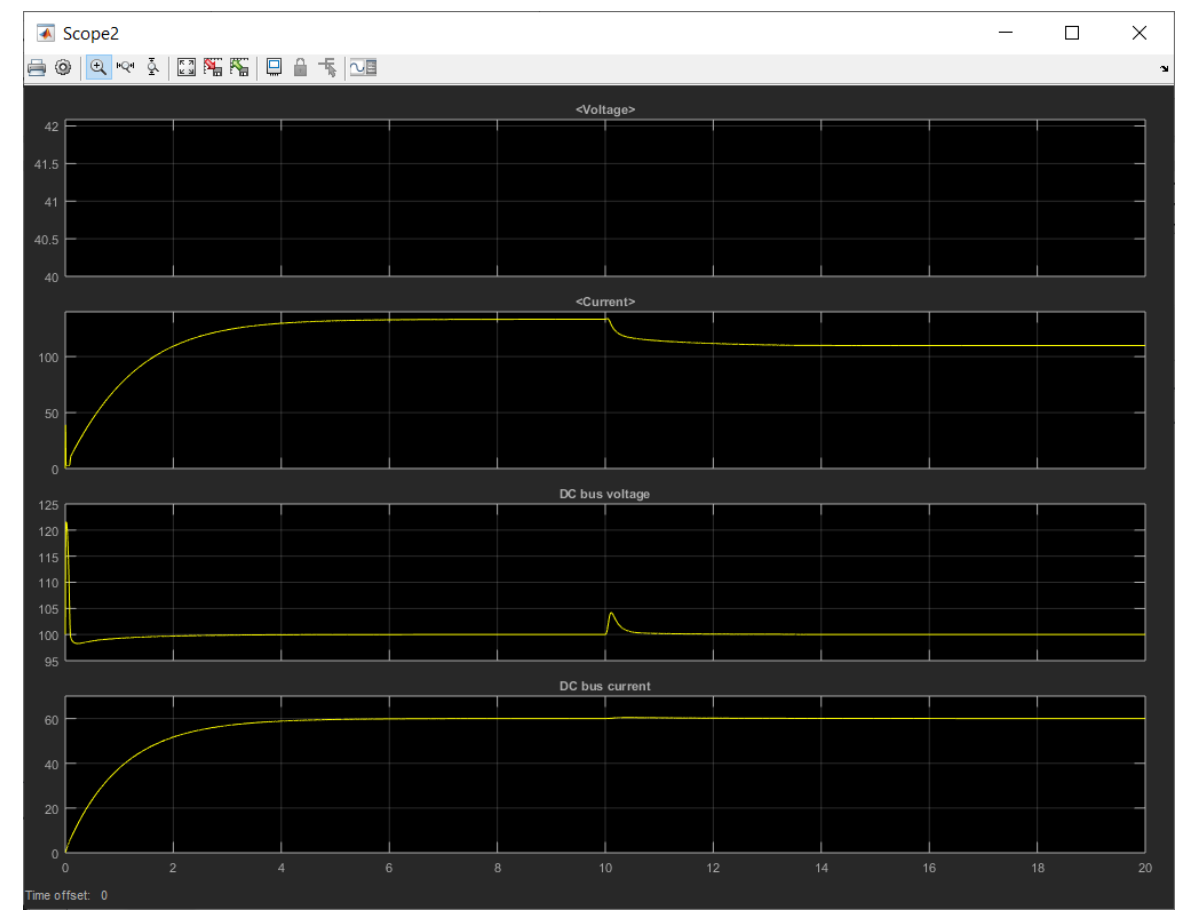

Fig. 4. Basic characteristics of the systems

\section{Conclusion}

The structure of a graphical tool for modelling and simulation of hybrid fuel cell systems is developed and presented in the paper. The model of the tool combines modelling and simulation, statistical approaches, optimizing procedures of hybrid systems for different types of vehicles: cars, buses and boats. The tool is based on different four modules and could be upgrade with other additional functions. A software graphical tool is developed in a form of Graphical user interface, based on the presented model, using MATLAB@7.1 GUIDE template editor and systems functions. It allows adjustments at program level and addition of supplementary functions if necessary. The developed graphical tool will be helpful tool of the researchers in the field of hybrid systems for modelling, simulation, optimization and analyze the obtained results. The future research will be focus on test and assessment of this system.

\section{Acknowledgments}

This work was supported by the Bulgarian Ministry of Education and Science under the National Research Program E+: Low Carbon Energy for the Transport and Households, grant agreement D01-214/2018.

\section{References}

[1] Dayton, D.C.; Ratcli, M. \& Bain, R. (2001). Milestone completion report. Fuel cell integration - a study of the impacts of gas quality and impurities: Technical report, National Renewable Energy Laboratory

[2] Croitorescu, V. \& Jiga, G. (2010). Influence of Using a Hybrid Electric Powertrain Combined with an ICE Variable Displacement in Automotive Architecture. Annals of DAAAM for 2010 \& Proceedings of the 21st International DAAAM Symposium, Volume 21, No. 1, ISSN 1726-9679 ISBN 978-3-901509-73-5, Editor B. Katalinic, Published by DAAAM International, Vienna, Austria, EU, 2010

[3] Ruettinger, W.; Ilinich,O. \& Farrauto, R.J. (2003). A new generation of water gas shift Catalysts for fuel cell applications. Journal of Power Sources, 118,1-2, 61-65, ISSN: 0378-7753

[4] Wu, Y. \& Gao, H. W. (2006). Optimization of fuel cell and super capacitor for fuel-cell Electric vehicles. IEEE Transactionson Vehicular Technology, 55, 6, 1748-1755 
[5] Haris, L.; Adnan, C.; Mugdim, P.; Omerspahic, A. \& Dzaferovic, E. (2013). Optimization of Thermal Insulation and Regression Analysis of Fuel Consumption. Proceedings of the 24th DAAAM International Symposium on Intelligent Manufacturing and Automation, ISSN 1726-9679 ISBN 978-3-901509-73-5, Editor B. Katalinic, Published by DAAAM International, Vienna, Austria, EU, 2013, Procedia Engineering, 69, $902-910$

[6] Ang, S. M. C.; Brett, D. J. L. \& Fraga, E. S. (2010). A multi-objective optimization model for a general polymer electrolyte membrane fuel cell system. Journal of Power Sources, 195, 9, 2754-2763, ISSN: 0378-7753

[7] MATLAB Function Reference. The MathWorks, Inc. (2003).

[8] Schell, A.; Peng, H.; Tran, D.; Stamos, E.; Lin, C. C. \& Kim, M. J. (2005). Modelling and control strategy development for fuel cell electric vehicles. Annual Reviews in Control, 29, 1,159-1

[9] Dimitrov, V.; Punov, P. \& Arnaudov, D. (2019). Fuelcell power supply system - modelling and optimization. 2019 16th Conference on Electrical Machines, Drives and Power Systems (ELMA), 1-4.

[10] Ang, S.M.C.; Brett, D.J.L. \& Fraga, E.S. (2011). Fuel Cell Efficiency, chapter Optimal Design of fuel cell systems. Nova Science Publishers, Inc. New York.

[11] Haraldsson, K. \& Wipke, K. (2004). Evaluating PEM fuel cell system models. Journal of Power Sources, 126, 1, 88- 97, ISSN: 0378-7753

[12] Frangopoulos, C. A. \& Nakos, L. G. (2006). Development of a model for thermoeconomic design and operation optimization of a PEM fuel cell system. Energy, 31, 10-11, 1501-1519, ISSN: 0360-5442

[13] Biyikoglu, A. (2005). Review of proton exchange membrane fuel cell models. International Journal of Hydrogen Energy, 30, 11, 1181-1212, ISSN: 0360-3199

[14] Kim, M. J. \& Peng, H. (2007). Power management and design optimization of fuel cell/battery hybrid vehicles. Journal of Power Sources, 165, 2, 819-832, ISSN: 0378-7753

[15] Ang, S.M.C.; Fraga, E.S.; Brandon, N.P.; Samsatli, N.J. \& Brett, D.J.L. (2011). Fuel cell systems optimisation methods and strategies. International Journal of Hydrogen Energy. 36, 22, 14678-14703, ISSN: 0360-3199

[16] Okedu, K.E. \& Roland, U. (2014). Optimization of Renewable Energy Efficiency using HOMER, International Journal of Renewable Energy Research, 4, 2, 421-427, ISSN: 1309-0127

[17] Spiegel, C. (2008). PEM Fuel Cell Modeling and Simulation Using Matlab. 